\title{
WAS THE INDIAN MUTINY \\ CONSEQUENCE OF THE BREAKDOWN \\ OF THE BRITISH INFORMATION \\ SYSTEM?
}

Serkan BAYKUŞOGLU*

Citation/C): Baykuşoğlu, Serkan (2014).Was the Indian Mutiny Consequence of the Breakdown of the British Information System, Hitit University Journal of Social Sciences Institute, Year 7, Issue 1, June 2014, pp. 139-153.

Abstract: The Indian Mutiny has an important place in British Colonial History. There were various causes of this rebellion but this research, which was based on the original historical documents, showed that the main reason was the breakdown of the British Information System. This study also considered other aspects which played role in the mutiny such as delay in construction of telegraphic system and railways. Thus, the British government realised that a controlled information line in Indian as well as between India and Great Britain was vital. There was some improvement in governmental communications between the two countries but existence of the electric telegraph line was still slow and unreliable. Over thirty thousand soldiers including Muslims and Hindus rebelled together against the British authority. It spread out to other regions in Northern India involving princes and peasants. If the British authorities had sufficient and accurate information before the revolt occurred, this would not happen as the Empire's military power was strong enough to prevent such incident.

Key Words: Indian Mutiny, British Rule, Information System, Colonisation

\footnotetext{
*Researcher, University of Eastern Finland. e-posta:baykusoglu76@yahoo.co.uk
} 
Atıf/ (C): Baykuşoğlu, Serkan (2014). Was the Indian Mutiny Consequence of the Breakdown of the British Information System, Hitit Universitesi Sosyal Bilimler Enstitüsü Dergisi, Yıl 7, Sayı 1, Haziran 2014, ss. 139-153.

Özet: Hint Ayaklanması İngiliz Sömürgecilik Tarihi'nde önemli bir yere sahiptir. Bu isyanın birçok sebebleri vardır ancak orijinal tarihi kaynaklara dayalı olarak yapılan bu geniş çaplı araştırma isyanın asıl sebebinin İngiliz iletişim sisteminin çöküşünden dolayı olduğunu göstermiştir. Bu araştırma aynı zamanda telegraf ve tren hatlarının inşasının gecikmesi gibi isyanda rol oynayan diğer sebebleri de değerlendirmiştir. Böylece İngiliz hükümeti Hindistan ve Büyük Britanya arasındaki iletişim hattının yanısıra Hindistan içinde de kontrollü informasyon hattının öneminin farkına varmıştır. İki ülke arasındaki resmi iletişimde göze çarpan bir ilerleme görülsede o dönemde kullanımda olan telegraf hattı yavaş ve güvenilmezdi. Otuz binin üzerinde Müslüman ve Hintlilerin de içinde bulunduğu askerler hep birlikte Ingiliz yönetimine karşı isyan ettiler. İsyan Kuzey Hindistan'daki diğer bölgelere ve bu bölgelerde yaşayan prenses ve köylüleri de içine alacak şekilde yayıldı. Eğer İngiliz yönetimi isyan öncesi yeterli ve düzenli bilgiye sahip olsayd, isyan çıkmayabilirdi ki İmparatorluğun askeri birliği bu tür isyanları önleyebilecek bir güce sahibti.

Anahtar Kelimeler: Hindistan İsyanı, İngiliz Yönetimi, İnformasyon Sistemi, Sömürgecilik

\section{INTRODUCTION}

The Indian Mutiny, is also known as the Sepoy Rebellion, started at Meerut, North Central India, on Io May I857 and spread to other parts of Northern India.' 35 thousand Indian troops revolted against British authority while they were in the service of the English East India Company. ${ }^{2}$ It soon involved princes, landlords and peasants. However, on 14 September 1857 the British forces recaptured Delhi and the uprising took four months to peter out.

The causes of the revolt varied, such as the Indian soldiers who were dissatisfied with their pay and certain changes were made in regulations which were understood or interpreted, as a part of a plan, to force them to adopt Christianity. This doubt also found a basis in the introduction of cartridges that were lubricated with the fat of cows and pigs, which, in both Hindus and Muslims' religions, was not acceptable. Nevertheless, Benjamin Disrael. ${ }^{3}$ believed that the Mutiny was a revolt against the policies employed by the company in the name of Britain, not a protest against the violation of religious taboos. ${ }^{4}$ Likewise, it was said that Indians preferred their old customs, old traditions and dynasties. Syed Ahmad Khan, on the other hand, described the causes of the Indian revolt in a different way. ${ }^{5}$ 
However, I argue that the Indian mutiny was a consequence of the breakdown of British information system. If the British had enough and accurate information before the mutiny occurred the general causes of this revolt, which I expressed above, would have only been problems the British faced during the colonisation of India. They thereupon could easily have been solved, because British military power was sufficiently strong to prevent this type of revolt. On the other hand, it was not a war of Indian independence, as it was described by some historians. Therefore, the British could not get necessary information before the mutiny, because of the reasons that I will explain in this research.

To sum up, I thus will use important evidence to support my case through this study and I will also consider other aspects such as the British government's weakness in construction of telegraphic system and railways, which delayed establishing a proper information system before the mutiny. Hence, the British information system was disrupted by mutineers. ${ }^{6}$ And thereby the British government realised the necessity of having a British-controlled information line in India as well as between India and Great Britain.

\section{INFORMATION SYSTEM}

Firstly, the Mughals were never absolute masters of all India; there were many remote, inaccessible regions where their will never penetrated. There were also areas, particularly in central India, where their authority depended on the submission and co-operation at local princes7. Furthermore, the people of India were from the different backgrounds and beliefs as well as from various language communities such as Indian Persian, Hindustani Urdu, and the various forms of Hindu. As a result Indians from different regions even had difficulties in communicating with each other. Thus, simple difficulties of language made the Europeans initially dependent on the skills of linguists \& translators. Therefore, it would not be easy for the British to establish an accurate information system in the whole of India. Initially, in fact, it was important for the British to understand the different cultures, races, and different degrees of power of the conquered societies especially while it was also attempting not to mix the British genes with others.

Before the 1760 s British commercial knowledge was never as full as that of the Dutch who gained access to Mughal customs records. The British did not achieve this until after they gained direct control of Indian Territory ${ }^{8}$. Thus, without good political and military intelligence the British would never have established their rule in India.

In pre-colonial India surveillance was important and so chief police officers (Kotwal) of the towns observed every house and brought in reports which were recorded in the police diary of the towns. These reports were also passed through 
to the intelligence officials of the court. Likewise, Chief registrars (Kanungo) maintained data that was stored in the records of the villages' accountants and this data was checked by state officials.

The 'Post' was a private system protected by the ruler, and the political elite relied heavily on the information provided by knowledgeable people: physicians, astrologers and men of religion. ${ }^{9}$ First, the state's information system, though effective at its best, was peculiarly dependent on the collaboration of local elites to keep the runners running and the newsletters flowing. However, the system declined or was subverted by the Mughal Empire's Maratha and Sikh enemies. ${ }^{10}$ Beside this, the link between the professional runner and writer system and the village or urban quarter was weak, mediated as it was by headmen and other agents who were part of the village or neighbourhood community and owed ultimate loyalty to it. The state could not communicate with its subjects easily. ${ }^{\text {II }}$

Therefore, during the years of conquest of the British, Royal intelligence was heavily dependent on informal networks of knowledgeable people. The British gained information about the country from Indian sources and Indian agents. Between 1760 and I860s via networks Indian running spies, news writers (Munshi), scribes, runners, astrologers, physicians, experts, midwives, marriage brokers who carried day-to-day information and other knowledgeable people brought news from one community and region to another. However, until the I78os, little information about the region came from the direct observation of European officers.

The East India Company, during the colonisation of India, had dual information system. At the upper levels, in the revenue, machinery, army and political service, a considerable concentration of information and power had been achieved. At the lower levels, however, the older system of decentralised intelligence communities continued. ${ }^{12}$ The link between state-level and community information systems, always weak, could easily be severed. This happened during the 1857 rebellion. ${ }^{13}$

\section{TELEGRAPHIC LINES, RAILWAYS AND ROADS}

One of the most important ways of communication would be establishing telegraph lines in India which, however, was not considered by the British authorities until the I85os. The Marques of Dalhousie wrote about the plan of electric telegraphs in his letter, saying;

"I have started also a large experiment on electric telegraphs for India for success in Western is not conclusive as to the success of this great agent in these electrical climes and Post Office reform and other lesser affairs. It has been tremendous work; but a deal has been done, and I am well pleased on the whole". ${ }^{14}$

(Dak Bungalow, Kyrasole, April I6th I850) 
The deal had been done according to Marques, but it took three years to start. However, this was described as a victory in his other letter. ${ }^{15}$ Despite Marques hopes to reduce the period of communication with England, discussions about the telegraphic communication between India and England had begun only two months before the mutiny in the House of Commons in March I857.

Sir Denham Norreys said, "he would beg to ask the Chancellor of the Exchequer whether Her Majesty's Government proposed to take any steps to establish telegraphic communication between England and India? The Chancellor of the Exchequer said,

"that a company had been formed for the purpose, with the intention of making line by the way of Seleucia up to Ja'bir Castle in the Persian Gulf. The Government and the East India Company had agreed to an arrangement with the Company, which involved various conditions, and by which they were prepared, when the work was completed to assist it as far as to guarantee certain interest to the shareholders under certain conditions" (Monday March 16, 1857). ${ }^{16}$

In answer to Sir Denham Norreys, Mr. Wilson said, that "the only line of telegraphic communication between India and Europe with regard to which the Government had at present entered into any engagements was the line going from Seleucia to Kornah, on the Persian Gulf. The company would have to years granted to them for making their arrangements, and, of course, in the mean time the Government would not entertain any other project" (Wednesday March I8, I857). ${ }^{17}$

I accept that governmental communications between India and England were improved by the existence of the electric telegraph, which, however, was still very slow and unreliable. By that means, it was a political disaster for the British government that a telegraphic line between India and Britain was not considered, until 1857. Thus, there was no telegraphic link with India before 1865. In January I857 British officials began negotiations for this route with the Ottoman government through Stratford de Redcliffe, their influential ambassador. They won the support of the grand vizier, Resid Pasha, and the foreign minister, Ali Pasha, leading promoters of the telegraph in the Ottoman Empire. ${ }^{18}$ In June of the same year, under the leadership of William P. Andrew, the European and Indian Junction Telegraph Company was established in London to link Britain with India via the Euphrates route. Andrew, a visionary entrepreneur of Victorian technology, had projected railway lines all over the globe. His plans for the Euphrates included a railway as well as the telegraph. ${ }^{19}$

The importance of this system was noted in a general report on the administration of the Punjab Territories. ${ }^{20}$ For example the first news of the outbreak of the mutiny in Meerut and the massacre in Delhi did not reach London until 26 
June I857, over six weeks after the events they described. The original telegram concerning the outbreak was despatched from Calcutta on I8 May I857, and went via Bombay to Suez and then from Alexandria to Trieste by steamer, thence by landwires to London. ${ }^{21}$ The mutiny, on the other hand, was carrying a risk that it would have spread over the whole India. General Sir George Digby Barker mentioned this risk in his letter, dated Ist July I857, saying:

"The Mutiny seems to have spread over the whole of India nearly, and unless large reinforcement are sent immediately from England, we should be in a dangerous position". ${ }^{22}$

Moreover, the British certainly had problems keeping open the 'secret weapon' the electric telegraph. On the other hand the rebels had even greater difficulty in communicating over long distances. Over short distances they had positive advantages: local guides who knew every step of the way between villages, supporters and sympathisers in large numbers throughout the countryside who would enthusiastically spy and report accurately. But over long distances it was another matter: frequently the rebels were deceived or inaccurately informed as to the outcome of major battles etc., and there is a distinct possibility that this lack of accurate intelligence had a significant bearing on the eventual outcome of the struggle. ${ }^{23}$

The situation of construction the railway in India was not different than to that of telegraphic lines. The British did not show enough attention to railway construction before 1857, thus, this became another factor for the British to be dependent on Indian informants. Otherwise, a proper rail network thorough India would be an advantage for the British to get fast and accurate information, which would definitely be vital in preventing the British breakdown of information. For example, in a report, about constructing the railway from Umritsur to Mooltan and the importance of railways, it was explained that ...Recent events have shown this line to be of the highest military and political importance in respect to maintaining British Rule in the Punjab. Its southern terminus, Mooltan, is the most important point on our line of communication with the sea, and would be our last place of resort in the event of disaster. ${ }^{24}$

However, In May 1857 the building of railways in India had only just begun. Many miles were planned, much engineering work had been set in motion, bridges built and embankments started: the skilled personnel were in situ, but the only railway actually operating ran for just 120 miles from Calcutta to Raniganj. ${ }^{25}$

I accept, on the other hand, that the railway project in India was not supported by the Indian Government, which Mr. Vernon Smith explained in the House of Commons, saying:

"The Indian Government had laid down no positive rule as to the granting of 
any future guarantees upon that subject...they naturally were not very desirous to extend that guarantee in the present state of the Indian finances" (20 February 1857) ${ }^{26}$ However, the question was if it would be profitable rather than importance of the railways for the British information system.

Roads were important, as well as telegraphic lines and railways, in communication. Thus, according to a report in 1859 , roads improved in India during the previous two years. After the siege of Delhi, it was confirmed that without the road to Delhi it might hardly have been possible to take Delhi, at least during the autumn of 1857 ! From this case, we can see the paramount necessity of improving our means of military communication. ${ }^{27}$

\section{BREAKDOWN IN THE BRITISH INFORMATION SYSTEM}

Until the rebellion of I857, the East India Company's colonial government was successful in getting information, through a flexible system, from its Indian informants. However, this did not mean that it would continue. Trust and lack of supervision of these people made them behave how they wanted, whereas the British were able to give new duties to these agencies. For example if you wanted multiple copies you had to have an army of scribes copying in copperplate handwriting. There was no secrecy about a printer's shop..$^{28}$ By the I83os, information, which was carried by news writers and runners, was kept into files and used by the Anglo-Indian press. This made the information known publicly, which should have been kept secret. Beside this, some pre-colonial institutions, religious establishments, merchant families, the officers of the army and revenue manager kept archives. ${ }^{29}$ The army also played an important role in storing information, mainly about the Indian subject and rural society.

As a result, individual leaders and communities who were thought to have benefited from British rule were often among the first to revolt. This resistance begun by a mutinous Soldiery, found support from the inhabitants of the City, and of the Province of Oude at large. Many who owed their prosperity to the British Government, as well as those who believed themselves aggrieved by it, joined in this cause, and ranged themselves with the enemies of the state. $3^{\circ}$ One example is Ahmud Ally Khan, the Nawab of Furrucknuggur, who was condemned to death by the Military Commission and executed at Delhi on 23rd January I858. As a result, the charges preferred against the Nawab were for holding correspondence with the rebels. ${ }^{31}$

Furthermore, one of the Nawabs had known that sepoys would rebel; however, the British were not informed. We learn this from a letter from Lucknow, which states that the zemindars of Julsipur and Sultapur and the country along the Ruver Yoyra have collected a body of 60.000 Sepoys and II2.000 of the country people to fight against the English and sent a letter to the Nawab. Nawab of Lucknow in 
Calcutta was asked to drive the English out of the Province, but the Nawab would not give his consent. Nevertheless, he sent instructions to the zemindars to keep quiet. ${ }^{32}$

Thus, the company's sophisticated system of local intelligence fell apart quite quickly as key information brokers defected at village and district level. ${ }^{33}$ This was later confirmed that we deeply lament the evils and misery which have been brought upon India by the acts of ambitious men, who have deceived their countrymen by false reports, and led them into rebellion. ${ }^{34}$ The British were depending on those news writers, scribes and runners, (which had first revealed) and the information thus had been cut. Furthermore, the Punjab newspapers and two Delhi newspapers continued to publish and carried rebel proclamations. The British media caused a problem during the mutiny. News about the revolt in Meerut was published in the British and Indian newspapers. This reached troops who began to mutiny. Take the sentence 'Lord Canning issued a Proclamation'. Today its contents would no doubt have been leaked to the press and known to the public even before it was issued. ${ }^{35}$ The coup took the British in Delhi completely by surprise. The events of the next few hours followed the same awful pattern as those in Meerut. Europeans were killed at random and attempts by their officers to rally the city's garrison ended in mutiny and murder. ${ }^{36}$ News of the revolt travelled very fast, which amazed the British.

Communications to Britain took approximately six weeks at this time and therefore initial reports of the disturbance did not reach London until the third week of June. Initially, very little attention was paid to the incoming reports as it was assumed that the mutiny was of a very limited nature and the situation would soon be under control.

Furthermore, there was no officer, except one, to communicate in regiments. This was expressed by the Calcutta Correspondent of the Times, saying: "So long as there is one officer in a regiment to whom the men can talk and in whom they place confidence there will be no mutinies. That regiments by the dozen should be left without one officer in that position is the reason why the ablest officers in India believe that the organisation of the line has become effete". 37

The British survived in parts of India because there was an electric telegraph. However, it was difficult to arrive at full certainty about the layout of the telegraph lines in the triangle Agra-Meerut-Delhi at this period...Both the Meerut-Delhi and the Meerut Agra lines were cut at the time of the outbreak, but at different times and in different circumstances. ${ }^{8}$ The outbreak was indeed premeditated and planned in advance among the Meerut troops, witness the report to Gough on the evening of 9 May and the cutting of the telegraph line to Delhi between gam and $4 \mathrm{pm}$ on the Ioth. 39 


\section{THE MUTINY OF INDIA QUESTION IN THE HOUSE OF COMMONS}

The Mutiny was discussed in the House of Commons on 29 June I857. It is clear from the discussion that this revolt was a surprise and the news reached Britain at the end of June. The government therefore knew more than they were willing to state publicly or they really did not have enough information to answer the questions raised in the House. The Earl of Ellenborough's expression was showing that the East India Company could not do anything to prevent the mutiny. The Earl of Ellenborough said:

“...the government of India had acted judiciously in issuing no Proclamation of that character. Now in the face of that opinion, I find by the news received this morning that not only the Lieutenant Governor of Agra but the Governor General in Council of India has issued a Proclamation in the strongest terms of the tenor I have described. But my Lords, upon what day was that Proclamation issued?... Now the issuing of that Proclamation at that moment might possibly tend to prevent the spread of the mutiny, but it could have no possible effect in preventing the outbreak. I desired to prevent the breaking out of the mutiny, and not only to keep it from spreading" (Monday, June 29, I857).40

Moreover, the British authorities had a little information about the incident which happened in Calcutta. This was also explained by the Earl, saying: "As long as the 22nd of January, an incendiary fire broke out in cantonments at a short distance from Calcutta, a thing almost entirely unknown and unheard of. From that period, for more than three months, these indications of the dissatisfaction of the troops continued to appear at all the principal stations of the army" (Monday, June 29, I857)..$^{4}$ In addition, The Earl of Ellenborough's views appeared in the Times on IO June I $857 \cdot^{42}$

Furthermore, the British were not informed, which gave the other troops a chance to revolt. On the 25 th of February the 19th regiment also mutinied. However, this regiment was not disbanded until the 3Ist of March.

"These indications of a bad spirit among the troops occurred at Allahabad, Agra, Meerut, Umballah, and all the great stations. No one can doubt that there was combination, and one general feeling animated the whole” ...At Meerut the Mutineers took the initiative. They rose at six o'clock in the evening, and according to the accounts we have received, it was not until nightfall that Her Majesty's carabineers were able to move" (Monday, June 29, 1857).43

The Earl of Ellenborough completed his speech, saying: "From all I have learnt I believe the measures which have been taken by the Government of India from the moment they heard of the occupation of Delhi have been prompt and judicious. I have no fault to find with their conduct since that period; but I do find fault 
with them for having been blind to that which ought to have been obvious to all, and for having taken no precautions before this dreadful calamity took place" (Monday, June 29, I857).44

To sum up, the discussion about the Mutiny of India in the House of Commons, could not be useful because of the lack of the official information. This was confirmed by Earl Granville. 45 saying: "In respect of what has fallen from the noble Earl in reference to the disaster at Meerut, it certainly appears, so far as we are able to judge, from the accounts that have come to hand-though it should be remembered that we have at present no official information as to the facts" (Monday, June 29, I857). $4^{6}$ Therefore, to decide what to do from Britain could not be possible until official information was received.

\section{CONCLUSION}

An unexpected revolt, the Indian Sepoy Mutiny, happened in India, which was under British control at the time of the rebellion, in 1857. Why the Sepoys rebelled has been questioned since then. There were many reasons for the Mutiny. However, only one main reason, on which I have focused in this work, was the breakdown of British information as a consequence of the mutiny, but it does not mean that I have ignored the other points when I came to a conclusion. I have therefore carefully considered much evidence to prove my argument.

Firstly, it is necessary to explain that before the British occupation of India there was no central authority. The country had been ruled by the Mughals and its local princes. The ruling system was divided and therefore there were difficulties in communication between regions. The flow of information was rather slow and weak. In addition, people of India were from different origins and speaker of varied languages. Thus, with the beginning of British rule in India there was no way to get information other than to be dependent on Indian agents. Through the Indians, such as spies, runners and news writers, the British collected information about the country. These agents were untrustworthy and were usually the first to rebel. However, the British followed the same policy to bring to an end the mutiny. Rose ${ }^{47}$ had no intelligence department and he depended primarily on Hamilton and his political assistants. They depended upon extensive use of Indian spies who seem to have been able to move freely, even within the rebel camps... $4^{8}$

Besides this, the information, which was carried by them, was leaked to the press. Thus, the people were informed before the East India Government. The British only tried to prevent this during the mutiny, but it was too late. "...in the persecution of the British Press, their last act being the suppression of the Bengal Hurkaru, the oldest daily News paper published in Bengal". ${ }^{49}$ Besides this, with the Indian Resolutions, more strict action was taken to control information. "That all despatches, letters, orders, and communications shall be addressed to 
the Secretary of State, and shall be open to the inspection of every member of the Council....". 50

The information system at this level was a decentralised and this was a big risk to take. As a result, the British realised when the mutiny occurred that this system was wrong and ineffective and so had to be changed. "To regulate the conduct of our functionaries, civil and military, in the territory which we recover, to introduce again some centralisation of system....". ${ }^{51}$

Secondly, over twelve regiments were left without officers. It was argued that there would be no mutinies if communication was set in regiments. This might be one of the reasons why the British did not hear anything about the fire, which happened in Calcutta in January I857. This was, on the other hand, an indication of the Meerut mutiny. Beside this, In Nepal (I814-1816), in Burma (I824-1826), and on the North-western frontiers through to the military debacle of $1832-42$ and beyond the British were often confronted by a virtual information famine, which slowed their advance and sometimes put the whole edifice of their power in peril..$^{2}$ These were signals of a big mutiny and the most important point is the British could not improve their information since these conflicts.

Furthermore, telegraphic lines, railways and roads were ignored by the British. Had they been improved, the British would have got information through this technological system about India. This would be more secure, fast and reliable. The news about anyone, who thought to rise in opposition or armed resistance to the authorities, could have reached the British before any plan could be made.

To sum up, when all the factors I have shown and the evidences I have gathered are considered, it is clear that the Indian Mutiny was the outcome of the failure of the British system of information. 


\section{NOTES}

[I] The other main centres of the rebellion were Allahabad, Mainpuru, Fatehgarh, Bareilly, Agra, Aligarh, Bulandshahr, and Delhi.

[2] "A telegraphic despatch received at Bombay from Meerut states that the $3 d$ Bengal cavalry were in open Mutiny. Several officers and men had been killed and wounded" The Times, 8 June Monday I857, p.9.

[3] First Earl of Beaconsfield (I804-188I), statesman and man of letters. see for more information: STEPHEN, Leslie (Sir) and LEE, Sidney (Sir). (1917), The Dictionary of National Biography, vol. V, Oxford University Press, p.Ioo6.

[4] The Time's Correspondent shared also same idea as Disraeli. He said, "The Mutiny is not instigated by any religious feeling. Every mutiny that has ever occurred in India has been apparently created by one of two causes a reduction of pay or an outrage on caste prejudice. The reason for that fact is simple enough. No other cause would ever induce three Sepoys to act together. They have no patriotism, for during 600 years they have had no country. They have no sense of a common interest in the common weal..." The Times, I5 June Monday I857, p.I2.

[5] According to him there was lack of understanding between ruler and ruled and the British had failed to use Hindu-Muslim differences to ensure the loyalty of the army.

[6] Evidence to this, Sir George Digby Barker saying in his letter: "You may as well direct my letters to me at Benares to be forwarded, but at present all postal communication is cut off beyond Allahabad. The telegraph has been cut by these murderous hounds and made into slings to fire at us", BARKER, Sir George Digby (General), Letters from Persia India I857-1858, (edited by Lady Barker), G. Bell and Sons ltd., London I915, p.46.

[7] JAMES, Lawrance. (1997), Raj The Making and Unmaking of British India, Little Brown and Company (UK), London, p.5.

[8] BAYLY, C. A. (Christopher Alan). (1997), An Empire of Information : Political Intelligence and Social Communication in North India, I780-1880, Cambridge University Press, $p .46$.

[9] Ibid., p.366.

[Io] Ibid., p.369.

[II] Ibid., p.369.

[12] Ibid., p.165.

[i3] Ibid., p.I65.

[I4] BAIRD, J. G. A. (I9II), Private Letters of the Marques of Dalhousie, William Blackwood and Sons, Edingurgh and London, p.II9.

[15] He said that "In November last we began to lay the electric telegraph. Five days ago I received a message from Agra, 800 miles distant, transmitted in I hour and 50 minutes! And I have a few minutes ago read the heads of intelligence of your mail of $24^{\text {th }}$ February by way of Bombay. In short time we shall complete the line to Bombay, and thus in a few months we shall reduced the period of 
communication with England from thirty-five to twenty-six days....We have already so improved communications that our last letter from Umerapoora was only nineteen days old. BAIRD, J.G.A. (I9II), Private Letters of the Marques of Dalhousie, William Blackwood and Sons, Edingurgh and London, p.293. (Government House, March 30 th 1854 )

[16] Hansard's Parliamentary Debates: $3^{\text {rd }}$ series, vol. CXLIV, 3 February I857-2I March 1857), 2366.

[I7] Ibid., 2427.

[18] BEKTAS, Yakup (2000), “The Sultan's Messenger: Cultural Constructions of Ottoman Telegraphy, I847-I880", Technology and Culture 4I.4, pp.669-696, p.679.

[19] Ibid., p.677.

[20] In the present report, it is indeed hard to describe how useful the telegraph has proved to the Punjab administration during the crisis of I857!... It were superfluous to mention the immense advantages which the Telegraph gave us over enemies. Suffice it to note the instance at Lahore, when the Authorities were warned by the telegraph of the Delhi disaster, disarmed the sepoys before they could obtain information by post. If there had been a telegraph, an outbreak at Lahore might possibly not have been averted at that moment. PRO 30/12/22, Supplement to the Overland Friend of India, General Report on the Administration of the Punjab Territories, For the Years I856-57 \& I857-58, Jan 22 I859, Section VI/Electric Telegraph/7o, p.I2.

[2I] HOSKINS, H.L. (1966), British Routes to India, London, p.9I.

[22] BARKER, Sir George Digby (General). (1915), Letters from Persia India I857-1858, (edited by Lady Barker), G. Bell and Sons ltd., London, p.40.

[23] TAYLOR, P.J.O. (1996), A Companion to the 'Indian Mutiny' of I857, Oxford University press, Oxford, p.9I-92.

[24] PRO 30/12/22, Supplement to the Overland Friend of India, General Report on the Administration of the Punjab Territories, For the Years I856-57 \& I857-58, Jan 22 I859, Section IV/Railroads/6I, p.II.

[25] TAYLOR, P.J.O. (1996), A Companion to the 'Indian Mutiny' of I857, Oxford University press, Oxford, p.279, please also see for similar comment; MACMunn, Sir George (Lieut-General). (193I), The Indian Mutiny in Perspective, London, p.22.

[26] Hansard's Parliamentary Debates: $3^{\text {rd }}$ series, vol. CXLIV, 3 February I857-2I March 1857), 934.

[27] PRO 30/12/22, Supplement to the Overland Friend of India, General Report on the Administration of the Punjab Territories, For the Years I856-57 \& I857-58, January 22, I859, Section IV, Part I-Roads, 55, p.IO.

[28] TAYLOR, P.J.O. (1996), A Companion to the 'Indian Mutiny' of I857, Oxford University press, Oxford, p.9I.

[29] BAYLY, C. A. (Christopher Alan). (1997), An Empire of Information: Political Intelligence and Social Communication in North India, I780-I880, Cambridge University Press, p. 372 .

[30] PRO 30/12/22, Extracts of a letter from the Secret Committee of the Court of Directors of the East India Company to the Governor General of India in 
Council, dated $19^{\text {th }}$ April 1858 , relating to that "Proclamation" $/ 7^{\text {th }}$ May 1858 , p.4. The Proclamations is addressed to the Chiefs and Inhabitants of Oudh.

[31] The Delhi Gazette, Saturday, August 7, 1858, The founding; Ahmud Ally Khan's defence was a complete failure, he merely asserts that he has never been faithful to the British Government, denies the correspondence with the king. See for more details about the charges which were made against the Nawab, PRO 30/12/22.

[32] PRO 30/29/23/IO, Letter from Muttra, $9^{\text {th }}$ June/320/32I.

[33] BAYLY, C. A. (Christopher Alan). (1997), An Empire of Information: Political Intelligence and Social Communication in North India, I780-I880, Cambridge University Press , 1997, p.336.

[34] PRO 30/12/22, Her Majesty's Proclamation Gazette, Governor-General's Camp Extraordinary, Published by authority, Allahabad, Monday, $\mathrm{I}^{\mathrm{st}}$ November I858, p.I7. Under the heading of "The Right Honourable the Governor-General has received the commands of Her Majesty the Queen to make known the following gracious Proclamation of Her Majesty to the Princes, the Chiefs, and the People of India".

[35] TAYLOR, P.J.O. (1996), A Companion to the 'Indian Mutiny' of I857, Oxford University press, Oxford, p.9I.

[36] JAMES, Lawrence. (1997), Raj The Making and Unmaking of British India, Little, Brown and Company (UK), London, p.240.

[37] The Times, I5 June Monday 1857 (the Bengal Mutinies), p.I2.

[38] PALMER, J.A.B. (1966), The Mutiny Outbreak at Meerut in I857, Cambridge University press, p.26.

[39] Ibid., p.I29.

[40] Hansard's Parliamentary Debates: $3^{\text {rd }}$ series, vol.CXLVI, I9th of June I857 to $17^{\text {th }}$ of July I857), 512-513.

[4I] Ibid., 512-513.

[42] The Times, Io June I857, (Parliamentary Debates). The Earl of Ellenborough "you must have looked with apprehension at similar appearances of mutiny in the Madras and Bombay armies; but that which has most alarmed me, and which gives a more serious character to all these appearances of insubordination is that which has only come to our knowledge within the last few hours... I can not but think that there must have been some strange misrepresentation and exaggeration in the accounts which we have received from India... When the $19^{\text {th }}$ Regiment was disbanded at Barrackpore there was a passage in a long official paper emanating from the Governor General in Council, and read to the soldiery, which was to the effect that no one could pretend that the Government had at any time endeavoured to interfere with the religion of the people; but I can not find that any notification has been made, as it should have been, at the quarters of every regiment and throughout the country... I see no trace of there have been any general notification to that effect. It has been left entirely to the officers at the different stations to make any such notification as they should think fit under the circumstances... And what should the course of the Governor General have been? Ought he not with his own hand in three sentences to have communicated to the whole country... I am convinced that if the Governor General had pursued that course we should have heard no more of the incendiary fires, nor of the open mutiny at Meerut. But that course was not taken...” 
[43] Hansard's Parliamentary Debates: $3^{\text {rd }}$ series, vol. CXLVI, I9th of June I857 to $17^{\text {th }}$ of July I857), 512-513.

[44] Ibid., 514.

[45] Gower, Granville (2 ${ }^{\text {nd }}$ Earl Granville), $1815-1891$, politician. He was born to diplomacy (his father was British Ambassador in Paris in the I830s). Look for further information; GARDINER, Juliet (edit.). (2000), The History Today Who's Who in British History, London, p.363.

[46] Hansard's Parliamentary Debates: $3^{\text {rd }}$ series, vol. CXLVI, i9th of June I857 to $17^{\text {th }}$ of July I857), 520 .

[47] Sir Hugh Rose, He came from a line of politicians and diplomats, but was commissioned into the $92^{\text {nd }}$ Highlanders in I82I. On the outbreak of the Mutiny he volunteered for service and was appointed to the Poona division. His campaign had done was to destroy the organised rebel armies and to occupy their bases. [48] ROBSON, Brian (Edit.). (2000), Sir Hugh Rose and the Central India Campaign, I858, published by Alan Sutton for the Army Records Society, Stroud, p.20. [49] PRO 30/12/22, Letter / Calcutta, 22 September I857, Mackey Co.

[50] PRO 30/12/22, The Indian Resolutions, Monday April 26 (The House of Commons)-Resolutions to be proposed by the Chancellor of the Exchequer on the $30^{\text {th }}$ of April, no: II.

[5I] PRO 30/29/23/10, Granville Papers, p.609.

[52] BAYLY, C. A. (Christopher Alan). (1997), An Empire of Information: Political Intelligence and Social Communication in North India, I780-I880, Cambridge University Press, $p .97$. 